\title{
Alignment Of Supply Chain Strategies And Practices Of Locally Made Vehicles In South Africa
}

\author{
Intaher Marcus Ambe, University of South Africa (UNISA), South Africa
}

\begin{abstract}
This paper sought to investigate the alignment between supply chain strategies and practices of local manufacturers of locally made light vehicles in South Africa. The research design employed was a combination of exploratory and descriptive research design using a qualitative approach. A face-to-face, semi-structured interview questionnaire was used, based on purposive sampling. Descriptive statistics using SPSS software was used for the data analysis and interpretation. The findings of the research revealed that across the supply chains of locally made models, all the manufacturers followed a lean strategy for their inbound supply chain and some had a lean supply chain strategy for their outbound supply chain. A number of them also had an agile supply chain strategy in the outbound supply chain, which suggests a leagile supply chain strategy. It was also found that in some instances there was a mismatch between strategies and practices in the area of product characteristics, manufacturing characteristics, and the decision drivers of the supply chain. Local manufacturers of locally made light vehicle models in South Africa do not always make decisions and implement practices in line with their chosen supply chain strategies.
\end{abstract}

Keywords: South Africa; Light Vehicle Manufacturers; Supply Chain Management; Strategies

\section{INTRODUCTION}

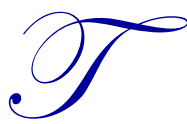

he turbulent market conditions today have heightened the need for alternative strategies for growth to be developed (Sanchez \& Perez, 2005, p. 681). A supply chain strategy is part of an overall business strategy, designed around a well-defined basis of competition (innovation, low cost, service, and quality) (Cohen \& Rousell, 2005, p. 10). Because of the need to align processes with trading partners, organisations must have clear strategic planning in order to effectively organise complicated resources, activities, communications, and processes to achieve a competitive advantage. There are two generic and widely accepted supply chain strategies: "lean" and "agile" (Fisher, 1997; Mason-Jones, Naylor, \& Towill, 2000; Christopher \& Towill, 2002; Vinodh, Sundararaj, \& Devadasan, 2009). Identifying the type of strategy (lean or agile) may be appropriate in various circumstances to position a product in an organisation's portfolio according to its supply and demand characteristics; the two strategies may also be combined, giving rise to a hybrid strategy called "leagile supply chain strategy."

Supply chain scholars have agreed that a supply chain strategy should be chosen on the basis of the type of product and by matching the strategy to the unique characteristics of different products or markets (Fisher, 1997; Lee, 2002; Sebastiao \& Golicic, 2008). Furthermore, a supply chain strategy must be matched with practice, because a mismatch generally leads to problems in the supply chain (Fisher, 1997; Christopher \& Towill, 2000). However, despite the well-recognised importance of research into supply chain strategy, there are limited empirical studies in developing economies, especially South Africa. Most of the studies on supply chain strategies are based in Western and highly developed countries (Qi, Boyer, \& Zhao, 2009, p. 668). While these studies have opened debate and discussion on supply chain strategies, generating new insights into Fisher's (1997) model, there remains a need to provide empirical evidence of supply chain strategies in developing economies. Although supply chain management (SCM) is a well-known concept in South Africa and in the automotive industry in particular, there is limited research into supply chain strategies. 
The automotive industry is the largest manufacturing sector in South Africa (Kehbila, Ertel, \& Brent, 2009, p. 310) and employs about 9 million people directly in producing vehicles and the automotive components that go into them (AIEC, 2012, p. 13). According to the AIEC report, it is estimated that each direct automotive job supports at least another five indirect jobs, resulting in more than 50 million jobs globally linked to the automotive industry. The industry sector's contribution to South Africa's gross domestic product (GDP) was R2,964 billion, or $6.8 \%$, in 2011. A compounded annual growth rate of $20.5 \%$ in rand value terms for completely built-up vehicles (CBUs) and automotive components exports was achieved from 1995 to 2011 (AIEC, 2012:13). South Africa currently exports vehicles to over 70 countries, such as Japan (around $29 \%$ of the value of total exports), Australia (20\%), the UK (12\%), and the US (11\%). African export destinations include Algeria, Zimbabwe, and Nigeria (SAinfo, 2008).

South Africa hosts seven multinational automotive companies that have mother companies in Asia (Japan), America, and Europe. These companies have different approaches to supply chain practices, organisational structures and cultural diversities and management styles. Therefore, there is a need to conduct a study to determine how these manufacturers align their supply chain strategies with practice. In light of this background, the purpose of this paper is to investigate how light vehicle manufacturers in South Africa align supply chain strategies with practice, in order to contribute to better understanding the industry. The paper reviews pertinent literature and discussions on the theoretical foundations and research questions. Subsequently, the empirical part of the study is described (research method and analysis of the results), and finally the conclusions of the study is presented.

\section{THEORETICAL BACKGROUND AND RESEARCH QUESTIONS}

Before discussing the theoretical background and research questions, SCM and supply chain strategy must be defined. SCM can be defined as a set of approaches that efficiently integrate and coordinate materials, information, and financial flows across the supply chain so that merchandise is supplied, produced, and distributed in the right quantities, to the right locations, at the right time, in the most cost-efficient way, while satisfying customer requirements (Shukla, Garg, \& Agarwal, 2011, p. 2059). A supply chain strategy, on the other hand, is part of the overall business strategy, designed around a well-defined basis of competition (innovation, low cost, service, quality) (Hines, 2006, p. 33). Qrunfleh and Tarafdar (2013, p. 573) asserted that supply chain strategy of a firm refers to the strategic goals and objectives of its supply chain. Strategies exist, whether they are planned or not. In other words all organisations have a de facto strategy. To be effective, an organisation's supply chain strategy must align with its competitive strategy (Chopra \& Meindl, 2010, p. 37).

There are two generic strategies in SCM, namely lean and agile strategies. "Lean" is a supply chain term defined as the "enhancement of value by the elimination of waste" (Womack \& Jones, 2003). A lean supply chain is concerned with cost reduction by operating the basic processes with a minimum of waste (Qi et al., 2009, p. 670). The primary objective of a lean supply chain can be realised by using the most basic forms of data communication on inventories, capacities, delivery plans, and fluctuations within the framework of just-in-time (JIT) principles (ElTawy \& Gallear, 2011, p. 817). Agility, on the other hand, is a comprehensive response to the business challenges of profiting from rapidly changing, continually fragmenting global markets for high-quality, high-performance, customer-configured goods and services (Iskanius, 2006, p. 93). Agility in the context of SCM focuses on "responsiveness." Li et al. (2008, p. 408) profess that, in today's complex and challenging supply chains, agility is critical to global competitiveness. An agile supply chain strategy, according to Ismail and Sharifi (2006, p. 432), is the ability of the supply chain as a whole, and its members, to rapidly align the network and its operations to the dynamic and turbulent requirements of the customers (Duarte \& Machado, 2011, p. 331).

Despite the distinguished characteristics of lean and agile systems, the two can be combined to form a hybrid system called a "leagile" supply chain. This system can be defined as "a system in which the advantages of leaness and agility are combined" (Krishnamurthy \& Yauch, 2007, p. 591). Leagile supply chains aim to infuse competitiveness into an organisation in a cost-effective manner. The combination of lean and agile paradigms within a total supply chain strategy enables the positioning of the decoupling point (Rahimnia, Moghadasian, \& Moghadasian, 2009, p. 81). In this hybrid strategy, lean focuses on waste elimination and achieving low-cost delivery of a standardised and stable product, while agility responds to complexity brought about by constant and unpredicted changes (Duarte \& Machado, 2011, p. 334). 
Fisher (1997) developed a model that helps managers determine their supply chain strategies based on the nature of the product (functional and innovative products). In addition to the product, there are other factors that might be used to determine the choice of a supply chain strategy (Lo \& Power, 2010, p. 141). These include: supply and demand characteristics (evolving versus stable supply) (Lee, 2002, p. 106); efficiency and responsiveness (Chopra \& Meindl, 2010, p. 44); structure and organisational relationships (Duarte \& Machado, 2011, p. 329); information technology and collaborative planning (Agarwal, Shankar, \& Tiwari, 2007, p. 443). In this regard, this paper discusses three categories of criterion that could be used to determine optimal supply chain strategies (Sayuti, 2011, p. 288). The paper holds that a supply chain strategy could be determined by aligning strategies with product characteristics, manufacturing characteristics, and decision drivers of supply chain as defined by the framework in Figure 1.

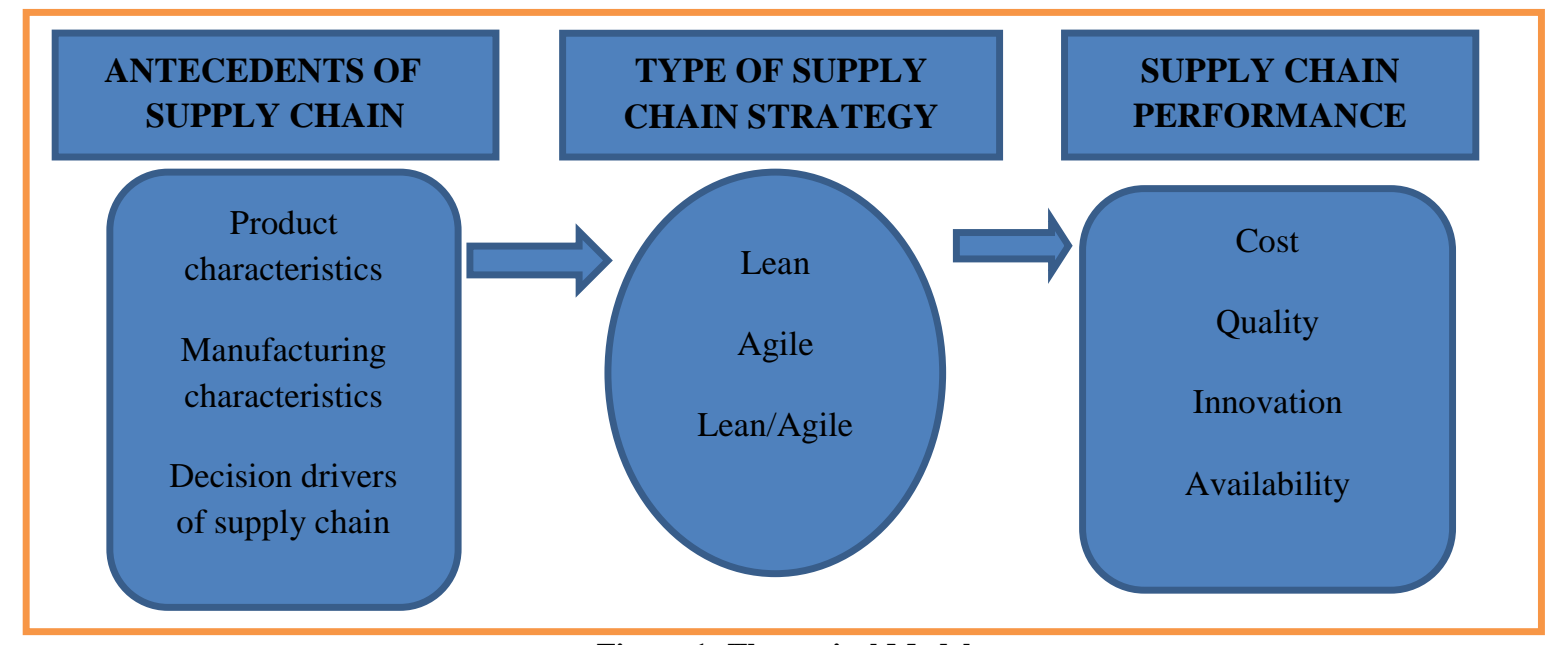

Figure 1: Theoretical Model

Figure 1 indicates that a supply chain strategy can be determined by the product characteristics, manufacturing characteristics, and decision drivers of the supply chain.

\section{Alignment of Supply Chain Strategies Based on Product Characteristics}

Two types of product in the market are functional and innovative products (Fisher, 1997, p. 106). In discussing the differences between functional and innovative products, it is necessary to consider which features of a product qualify it for selection by a customer (order qualifiers) and which features the product has that will cause the customer to choose it over competitors (order winners). Because of their substitutability, functional products tend to have price as their market winner (the customer can, after all, buy a nearly identical product easily from a competitor), while product quality, lead time, and availability are market qualifiers (Christopher \& Towill, 2002, p. 10). By contrast, availability (and inherently service level) is the market winner for innovative products, with quality, price, and lead time as the market qualifiers. That is, you cannot acquire a share of an innovative product's market unless the product is available for the public to purchase and has supporting high levels of service (MasonJones et al., 2000, p. 55).

These two product types respond to different marketplace pressures. Functional products have a predictable demand pattern and customers who expect lowest cost. Innovative products have volatile demand with customers who expect that supplies will be available to meet their demand. In reality, many products demonstrate both functional and innovative features, and there is a continuum with the extremes at either end. Functional products require a physically efficient supply chain, while innovative products require a market-responsive supply chain. The product life cycle for functional products is more than two years, while for innovative products it is three months to one year. Functional products have a low product variety of 10 to 20 variants per category, while product variety is high for innovative products. Moreover, the make-to-order lead time for functional products is six months to a year, while for innovative products it is one day to two weeks. 
Research Question 1: What are the supply chain strategies employed by light vehicle manufacturers based on the product characteristics?

\section{Alignment of Supply Chain Strategies Based on Manufacturing Characteristics}

The foundation for determining the relationship between manufacturing characteristics in this study is based on identifying four representative supply chains that are appropriate for different manufacturing environments. These include make-to-stock (MTS); assemble-to-order (ATO) or configure-to-order (CTO); maketo-order (MTO); and design-to-order (DTO) or engineer-to-order (ETO). In a MTS supply chain, the end consumer has no individual input into the configuration of the product, and typically purchases the product "as is" from a retailer. MTS supply chains are extremely common because they are appropriate for high-volume, low-profit-margin commodity products (Jonsson, 2008, p. 153). These low-cost products tend to have a relatively stable demand, which can therefore be forecast with a low degree of error when accurate historical demand information is available (Stavrulaki \& Davis, 2010, p. 134).

A CTO supply chain provides customers with a limited number of choices in the configuration of the final product. Customers can pick and choose from various standard components that are available in order to produce their own product, but have no control at the individual level in determining the design of these components. In order to offer customers a number of options, companies typically delay the final assembly of products until orders are received (Jonsson, 2008, p. 153). CTO supply chains are typically appropriate for higher-priced consumer goods that are assembled to individual end-customer specifications.

The MTO supply chain affords consumers the opportunity to have at least some part of the product uniquely built to their individual specifications. At the same time, the end consumer has no input into the overall design of the product, which remains fixed within the design parameters established by the firm. An MTO supply chain delivers customised, relatively expensive products that are specifically built to meet the needs of individual customers, although the actual design specifications have previously been established. These products are lowvolume and high-margin (Stavrulaki \& Davis, 2010, p. 138). Products made with the ETO supply chain represent the ultimate in customisation because there are virtually no constraints on customers with respect to incorporating their individual preferences and requirements into the final design of the product (Stavrulaki \& Davis, 2010, p. 140). Hence, products from ETO are by definition low volume (often volumes of one), with highly variable characteristics, and have high prices (Stavrulaki \& Davis, 2010, p. 142).

All processes in the supply chains discussed above fall into one of two categories: push or pull. In the push process, production is authorised on the basis of forecasting, which is in advance of customer orders (Jonsson, 2008, p. 268). In the pull process, however, the final assembly is triggered by customer orders. In a pure push process, MTS is the primary production approach. Demand is forecasted on the basis of historical sales data. The need from the end users is satisfied from inventory. Production lead time is relatively long and finished goods inventory is larger than that in the pull system. In the pull approach, end users trigger the production process (Chopra \& Meindl, 2010, p. 70). The major production strategies are MTO, CTO, and ETO. In a pull scenario, demand uncertainty is higher and cycle time is shorter than in the push approach. In this process, finished goods inventory is minimal (Taylor, 2004, p. 29).

Research Question 2: What are the supply chain strategies of light vehicle manufacturers based on manufacturing characteristics?

\section{Alignment of Supply Chain Strategies Based on the Decision Drivers of SCM}

Supply chain decision drivers examined in this study include: production (facilities); inventory; location; transportation; information; sourcing; pricing; supplier selection; alliances; and relationships, as briefly discussed below.

- $\quad$ Production: The fundamental decision that managers face when making production decisions is how to resolve the trade-off between responsiveness and efficiency (Taylor, 2004, p. 21). To be responsive, a 
company can do its production in many smaller plants that are close to major groups of customers so that delivery times are shorter. If efficiency is desirable, then a company can build factories with little excess capacity and have the factories optimised for producing a limited range of items. Further efficiency can be gained by centralising production in large central plants to obtain better economies of scale (Chopra \& Meindl, 2010, p. 62).

- Inventory: Inventory is spread throughout the supply chain and includes everything from raw material to work in progress to finished goods that are held by manufacturers, distributors, and retailers in a supply chain (Taylor, 2004, p. 22). Holding large amounts of inventory allows a company or an entire supply chain to be extremely responsive to fluctuations in customer demand (Bowersox et al., 2010, p. 157). However, the creation and storage of inventory are a cost, and to achieve high levels of efficiency, the cost of inventory should be kept as low as possible. An organisation can be responsive by stocking high levels of inventory for a wide range of products (Chopra \& Meindl, 2010, p. 65).

- Location: Location decisions include the decisions relating to which activities should be performed in each facility. The responsiveness versus efficiency trade-off here is reflected in deciding whether to centralise activities in fewer locations to gain economies of scale and efficiency, or to decentralise activities in many locations close to customers and suppliers in order for operations to be more responsive (Chopra \& Meindl, 2010, p. 63). When making location decisions, managers need to consider a range of factors relating to a given location, including the cost of facilities, the cost of labour, skills available in the workforce, infrastructure conditions, taxes and tariffs, and proximity to suppliers and customers.

- Transportation: In transportation decisions, the trade-off between responsiveness and efficiency is manifested in the choice of transport mode (Taylor, 2004, p. 23). Fast modes of transportation such as aeroplanes are highly responsive, but also more costly. Slower modes such as ship and rail are extremely cost-efficient but not as responsive. Since transportation costs can make up as much as a third of the operating cost of a supply chain, decisions made here are crucial (Jonsson, 2008, p. 64). According to Chopra and Meindl (2010, p. 65), responsiveness can be achieved by a transportation mode that is fast and flexible. Many companies that sell products through catalogues or over the internet are able to provide high levels of responsiveness by using transportation to deliver their products, often within 24 hours $(\mathrm{Nel} \&$ Badenhorst-Weiss, 2010, p. 211).

- Information: Information is the basis upon which decisions are made about the other four supply chain drivers. The power of this driver grows stronger each year as the technology for collecting and sharing information becomes more widespread, easier to use, and less expensive. High levels of responsiveness can be achieved when companies collect and share accurate and timely data generated by the operations of the other four drivers (Nel \& Badenhorst-Weiss, 2010, p. 211).

- $\quad$ Sourcing: Sourcing decisions are crucial because they affect the level of efficiency and responsiveness the supply chain can achieve. Outsourcing certain processes to other parties can increase a supply chain's efficiency, but may reduce its responsiveness because of possible longer lead time to achieve economies of scale (Nel \& Badenhorst-Weiss, 2010, p. 211). Outsourcing decisions should be driven by the desire for growth in total supply chain surplus (Chopra \& Meindl, 2010, p. 73).

- $\quad$ Pricing: Pricing affects the customer segments that choose to buy the product, as well as customer expectations. Customers expect low prices but are comfortable with a lower level of product availability. Steady prices also ensure that demand stays relatively stable. Pricing therefore affects the behaviour of the buyer of the product, thus affecting supply chain performance. Customers who value responsiveness will pay more for higher levels of customer service (Nel \& Badenhorst-Weiss, 2010, p. 211).

Research Question 3: What are the supply chain strategies of light vehicle manufacturers based on the decision drivers of the supply chain?

Table 1 summarises the instruments for determining practices of lean and agile supply chains based on product characteristics, manufacturing characteristics, and decision drivers of SCM. 
Table 1: Instruments for Determining Supply Chain Strategies

\begin{tabular}{|c|c|c|c|}
\hline $\begin{array}{l}\text { Supply Chain } \\
\text { Instrument }\end{array}$ & $\begin{array}{c}\text { Elements of Supply Chain } \\
\text { Instrument }\end{array}$ & Lean Supply Chain & Agile Supply Chain \\
\hline \multirow{6}{*}{$\begin{array}{l}\text { Product } \\
\text { characteristics }\end{array}$} & Type of product & - Functional products & - Innovative products \\
\hline & Order lead time & - Long order lead time & - Short order lead time \\
\hline & Demand uncertainty & - Predictable product & - Unpredictable product \\
\hline & Market winner & - Cost & - Availability \\
\hline & Product life cycle & - Long & - Short \\
\hline & Product variety & - Low & - High \\
\hline \multirow{3}{*}{$\begin{array}{l}\text { Manufacturing } \\
\text { characteristics }\end{array}$} & Product & - Standard (functional) & - Customised (innovative) \\
\hline & Manufacturing strategies & - MTS & - $\mathrm{ATO}, \mathrm{MTO}, \mathrm{ETO}$ \\
\hline & Manufacturing process & - Push supply & - Pull supply \\
\hline \multirow{7}{*}{$\begin{array}{l}\text { Decision drivers of } \\
\text { the supply chain }\end{array}$} & Production & $\begin{array}{l}\text { - Little excess capacity } \\
\text { - Narrow focus } \\
\text { - Few central plants } \\
\end{array}$ & $\begin{array}{ll}\text { - } & \text { Excess capacity } \\
\text { - } & \text { Flexible manufacturing } \\
\text { - } & \text { Many small factories } \\
\end{array}$ \\
\hline & Inventory & $\begin{array}{ll}\text { - Low inventory levels } \\
\text { - Fewer items } \\
\end{array}$ & $\begin{array}{ll}\text { - } & \text { High inventory levels } \\
\text { - } & \text { Wide range of items } \\
\end{array}$ \\
\hline & Location & $\begin{array}{l}\text { - Few central locations serve } \\
\text { wide areas }\end{array}$ & $\begin{array}{l}\text { - Many locations close to } \\
\text { customers }\end{array}$ \\
\hline & Transportation & $\begin{array}{l}\text { - Shipments few, large } \\
\text { - Slow, cheaper modes } \\
\end{array}$ & $\begin{array}{ll}\text { - } & \text { Frequent shipments } \\
\text { - } & \text { Fast and flexible mode }\end{array}$ \\
\hline & Information & $\begin{array}{l}\text { - Cost of information declines } \\
\text { while other costs rise }\end{array}$ & $\begin{array}{l}\text { - Collect and share timely, } \\
\text { accurate data }\end{array}$ \\
\hline & Sourcing & $\begin{array}{l}\text { - Supplier selection criteria } \\
\text { based on low prices }\end{array}$ & $\begin{array}{l}\text { - Supplier selection criteria } \\
\text { based on high service levels }\end{array}$ \\
\hline & Pricing & $\begin{array}{l}\text { - Pricing is a key means for } \\
\text { balancing supply and demand } \\
\text { - Based on low margins and } \\
\text { high volumes }\end{array}$ & $\begin{array}{l}\text { - Pricing does not normally } \\
\text { impact on short-term demand } \\
\text { - Based on high margins }\end{array}$ \\
\hline
\end{tabular}

\section{RESEARCH METHODOLOGY}

The paper is exploratory and descriptive, using a qualitative approach based on a survey of light vehicle manufacturers in South Africa. The target population for the research was locally manufactured (assembled) light vehicle manufacturers (original equipment manufacturers (OEMs)) in the South African automobile industry (total target population). Major international assemblers and manufacturers have established operations in South Africa, including OEMs from traditional manufacturing powerhouses in the US, Japan, and Europe, where key decisions about their manufacturing are made. Most of the global motor vehicle branded manufacturers are represented in South Africa. These include Toyota, BMW, Volkswagen, DaimlerChrysler, Nissan, General Motors, Ford (incorporating Mazda, Land Rover, and Volvo), and Fiat. Some of the OEMs manufacture certain models locally for the local market and also export some of their production outputs. These manufacturers are the focus of this study. Fiat currently does not assemble vehicles in South Africa, hence there are seven automotive manufacturers included in the study. These automotive manufacturer operations are concentrated in four South African cities: Pretoria, Durban, East London, and Port Elizabeth (Alfaro et al., 2012, p. 15).

The South African automotive industry produces two broad categories of vehicle - passenger vehicles and commercial vehicles. Passenger vehicles are classified from A to D class, premium, and SUVs, while commercial vehicles are categorised into light commercial, medium commercial, and heavy commercial. Passenger vehicle and light commercial vehicles are termed "light vehicles." One manufacturer may have various production lines with various supply chain strategies for each one. This is because supply chain strategies are unique to a production line and not the supply chain in general, as indicated by Fisher (1997). This research focuses on one production line (model) for each of the manufacturers, thus the population for the study constitutes light vehicle (passenger and light commercial vehicle) manufacturers. Light vehicle manufacturers were chosen, firstly, because this would incorporate all the automotive manufacturers in South Africa. Secondly, both categories of vehicle are used for 
personal purposes and therefore require distinctive features and characteristics. Table 2 presents the various models of passenger and light commercial vehicles assembled in South Africa.

Table 2: Light Vehicle Manufacturers and Local Manufactured Models in South Africa, 2011

\begin{tabular}{|l|c|c|c|}
\hline \multicolumn{2}{|c|}{ Passenger Vehicles (2011) } & \multicolumn{2}{c|}{ Light Commercial (2011) } \\
\hline \multicolumn{1}{|c|}{ Manufacturer } & Models & Manufacturer & Models \\
\hline BMW & 3-series, 4-door & Nissan & Hardbody, NP300, NP200 \\
\hline Mercedes-Benz & C-Class 4-door & Ford & Bantam and Ranger \\
\hline Nissan & Tiida, Livina/Grand Livina & General Motors & Chev Utility and Isuzu KB \\
\hline Toyota & Corolla 4-door and Fortuner & Mercedes-Benz & Mitsubishi Triton \\
\hline Ford & Icon and Focus & &
\end{tabular}

Source: AIEC (2012)

In this paper the total target population was used (all light vehicle manufacturers in South Africa) and because the study required in-depth understanding of SCM strategies and practices to investigate alignment, purposive sampling was used. Purposive sampling focused on those who have expert knowledge of supply chain practices and operations (senior supply chain managers). In this sampling technique, a researcher stipulates certain important criteria to be used or waits to be informed of the setting for the sample (Babbie \& Mouton, 2007, p. 287). The basic criteria used for choosing the respondents were, firstly, that the company was a local manufacturer of light vehicles in South Africa, and secondly, that the respondent was an employee at a senior SCM position in that lightvehicle manufacturing company. Specific participants for interviews were thus selected according to their strategic positions in the supply chain. In some companies, more than one respondent had to participate in the interview process to complete different parts of the questionnaire.

Both primary and secondary sources of data were used. Primary sources of data were interviews and observations (McGivern, 2006, p. 62). In this research, two sets of face-to-face interviews were conducted with senior supply chain actors. In the first set, five $(\mathrm{N}=5)$ in-depth interviews were conducted at two automotive manufacturers (pilot study) using open-ended questions. The interviews were intended to gain an understanding of the industry and supply chain practices. The interviews lasted on average an hour and 30 minutes and were recorded using a voice recorder and later coded. Themes from the code and the extensive literature review were used to compile structured questions for the second set of interviews. In the second set of interviews, face-to-face interviews were conducted with a total of 12 respondents from six of the seven light vehicle manufacturers in South Africa. A semi-structured interview questionnaire was used to elicit the opinions of the respondents on supply chain strategies and practices.

The interviews were conducted at different manufacturers for a particular locally manufactured car (model). As indicated by Fisher (1997), a supply chain strategy is dependent not on a supply chain but on a product (or in this study a model). Therefore, in this study, the interviewees who were senior supply chain managers had to identify a locally manufactured model (production line) on which the interview was then based. A total of $12(\mathrm{~N}=$ 12) in-depth interviews were conducted for six different models at six local manufacturers. In some instances, more than one interview was conducted at a manufacturer to gain a better understanding. Also, in other situations, more than one respondent completed different sections of the interview questionnaire, because of the differences in the organisational structures of the companies. Six models were identified, one from each manufacturer, as indicated in Table 3. The constructs in the questions were measured using a five-point Likert-type response format with end points (1) "strongly disagree" to (5) "strongly agree."

Table 3: Light Vehicle Manufacturers and the Chosen Models

\begin{tabular}{|l|c|c|}
\hline \multicolumn{1}{|c|}{ Manufacturer } & Production Line & No. of Interviews \\
\hline European manufacturer 1 & Model X & 2 \\
\hline American manufacturer & Model J & 2 \\
\hline European manufacturer 2 & Model Y & 1 \\
\hline Asian manufacturer 1 & Model Z & 4 \\
\hline Asian manufacturer 2 & Model W & 1 \\
\hline European manufacturer 3 & Model U & 2 \\
\hline Total number of in-depth interviews & & $\mathbf{1 2}$ \\
\hline
\end{tabular}


The data was analysed descriptively using Statistical Package for Social Sciences (SPSS). Descriptive statistics were used to describe the main features of the data in quantitative terms (Gray et al., 2007, p. 44). The result is presented in mean value scores. To ensure validity and to minimise the threat of inaccurately describing information received from face-to-face interviews, an interview diary was kept of what was said and discussed. In addition, questions had to be reformulated during the interview if the question was not understood and was thus difficult to interpret. In order to maintain reliability, consistent procedures were used.

\section{RESULTS AND DISCUSSION}

This section of the paper discusses supply chain strategies employed by light vehicle manufacturers in South Africa. As indicated in the literature study, supply chain strategies are based on a particular locally made model (car) or production line. The findings relating to strategies should therefore be interpreted for the particular model and are not necessarily applicable to other models manufactured by the same company. The results of the study are discussed in relation to the research questions and presented in frequency distribution (in percentages) per statement and mean level of agreement.

Research Question 1: What are the supply chain strategies of different manufacturers by product characteristics?

In this question, respondents were asked to rate their agreement with statements relating to the product (car model) characteristics, measured using a five-point Likert response format with the end points (1) "strongly disagree" and (5) "strongly agree." Table 4 presents the mean level of agreement of the manufacturers based on the product characteristics per manufacturer represented by mean values. ${ }^{1}$

Table 4: Responses Regarding Product Characteristics by Manufacturer

\begin{tabular}{|c|c|c|c|c|c|c|}
\hline \multirow{2}{*}{ Statements } & \multicolumn{6}{|c|}{ Mean Level of Agreement } \\
\hline & E1 & $\mathbf{A M}$ & $\mathbf{E 2}$ & A1 & A2 & $\mathbf{E 3}$ \\
\hline The model is a standard vehicle (no customisation). & 1.00 & 4.50 & 2.00 & 3.25 & 4.00 & 2.50 \\
\hline The demand for the model (vehicle) is stable. & 2.50 & 4.50 & 4.00 & 4.00 & 4.00 & 3.00 \\
\hline $\begin{array}{l}\text { The market winner (most important sales criterion/point) for the } \\
\text { model is cost. }\end{array}$ & 2.00 & 5.00 & 2.00 & 3.75 & 1.00 & 2.00 \\
\hline $\begin{array}{l}\text { The order lead time (order to delivery) takes more than three } \\
\text { months. }\end{array}$ & 1.50 & 2.00 & 2.00 & 3.00 & 2.00 & 2.00 \\
\hline Our forecast for the model is relatively accurate. & 2.00 & 3.50 & 4.00 & 4.00 & 4.00 & 4.00 \\
\hline
\end{tabular}

The results in Table 4 indicate that, on average, European manufacturers E1, E2, and E3 tended to disagree that the model was a standard vehicle (means of 1.00, 2.00, and 2.50 respectively), while the American manufacturer and Asian manufacturer 2 agreed (means of 4.50 and 4.00 respectively). Most of the manufacturers (American manufacturer, European manufacturer 2, and Asian manufacturers A1 and A2) agreed that demand for the vehicle was stable. The American manufacturer strongly agreed that the market winner for the vehicle was cost (a mean of 5.00), while four of the manufacturers (European manufacturers E1, E2, and E3 and Asian manufacturer A2) disagreed that the market winner was cost (a mean of 1.00 to 2.00). The majority of the manufacturers did not agree that the order lead time for the product was more than three months (means of 1.00 to 2.00). European manufacturer E1 disagreed that it implemented relatively accurate forecasting (mean of 2.00), while most of the manufacturers agreed that they did (mean of 4.00). The result shows that the models of all the European manufacturers (E1, E2, and E3) were not standard products (functional). While the E2 model was not a functional product, the demand for the vehicle was stable - hence a mismatch in the product characteristics. All the manufacturers agreed, on average, that the order delivery lead time took less than three months.

This result of the research shows that light vehicle manufacturers in the South African automotive industry assemble not only pure standardised vehicles, but also some that are customised. Most of the vehicles have relatively stable demand as well as relatively accurate forecasting for the model, indicating a functional product (associated

\footnotetext{
${ }^{1}$ For the purposes of analysis the following abbreviations were used: $E 1$ for European manufacturer 1; E2 for European manufacturer 2; E3 for European manufacturer 3; $A M$ for American manufacturer; $A 1$ for Asian manufacturer 1; and $A 2$ for Asian manufacturer 2.
} 
with lean supply chain strategy) (83.3\% and $75.0 \%$ agreement respectively). The vehicles had the characteristics of both functional and innovative products, implying they should practise lean and agile supply chain strategies. Owing to the fact that functional products follow a lean supply chain while innovative products follow an agile supply chain, there is a need to determine exactly which model (production line) followed what strategy. A portfolio matrix was developed to determine the mismatch between the product and the strategy. Characteristics of product types and market demand among the characteristics were matched against each other. Table 5 indicates the alignment between the selected product characteristics and supply chain strategies.

Table 5: Aligning Product Characteristics and Supply Chain Strategy

\begin{tabular}{|l|c|c|c|c|}
\hline \multirow{2}{*}{ Light Vehicle } & Key Product Characteristics & Mean & $\begin{array}{c}\text { Type of Product Based } \\
\text { on Characteristics }\end{array}$ & $\begin{array}{c}\text { Supply Chain Strategy } \\
\text { Based on Product Type }\end{array}$ \\
\hline \multirow{2}{*}{ E1 } & Model is standard & 1.00 & Innovative & Agile \\
\cline { 2 - 5 } & Demand is stable & 2.50 & Innovative & Agile \\
\hline \multirow{2}{*}{ AM } & Model is standard & 4.50 & Functional & Lean \\
\hline \multirow{2}{*}{ E2 } & Demand is stable & 4.50 & Functional & Agile \\
\hline \multirow{2}{*}{ A1 } & Model is standard & 2.00 & Innovative & Lean \\
\hline \multirow{2}{*}{ A2 } & Demand is stable & 4.00 & Functional & Lean \\
\cline { 2 - 5 } & Model is standard & 3.25 & Functional & Lean \\
\hline \multirow{2}{*}{ E3 } & Demand is stable & 4.00 & Functional & Lean \\
\cline { 2 - 5 } & Model is standard & 4.00 & Functional & Lean \\
\cline { 2 - 5 } & Demand is stable & 4.00 & Functional & Lean \\
\hline
\end{tabular}

As indicated in Table 5, the mean value was used against the demand characteristics to reflect the type of product (functional and innovative products). As discussed earlier, a functional product follows a lean supply chain and an innovative (customised) product an agile supply chain. Figure 1 provides a portfolio matrix for aligning product characteristics and the supply chain strategy.

\begin{tabular}{|c|c|c|}
\hline $\begin{array}{l}\text { Stable } \\
\text { demand }\end{array}$ & $\begin{array}{c}\text { MATCH } \\
\text { (LEAN SUPPLY CHAIN) } \\
\text { Asian manufacturers } 1 \& 2 \\
\text { American manufacturer }\end{array}$ & $\begin{array}{c}\text { MISMATCH } \\
\text { European manufacturers } 2 \& 3\end{array}$ \\
\hline \multirow[t]{2}{*}{$\begin{array}{l}\text { Volatile } \\
\text { demand }\end{array}$} & $\begin{array}{c}\text { MISMATCH } \\
\text { (AGILE SUPPLY CHAIN) } \\
\text { European manufacturer } 1\end{array}$ & МАТСН \\
\hline & Functional product & Innovative product \\
\hline
\end{tabular}

Figure 2: Portfolio Matrix for Product Characteristics

As indicated in Table 5, there was a mismatch in the relationship between product characteristics and supply chain strategies. From the portfolio matrix (Figure 2) Asian manufacturers 1 and 2, the American manufacturer, and European manufacturer 1 were correctly positioned (match). European manufacturers 2 and 3 were wrongly positioned (mismatch), because they indicated that their vehicle was an innovative (customised) product, but the demand was stable.

Research Question 2: What are the supply chain strategies of the different manufacturers based on manufacturing characteristics?

This part of the results deals with the responses on manufacturing characteristics according to the manufacturers. The results are presented using mean level of agreement scores as indicated in Table 6. 
Table 6: Responses Regarding Manufacturing Characteristics by Manufacturers

\begin{tabular}{|l|c|c|c|c|c|c|}
\hline \multicolumn{1}{|c|}{ Statements } & \multicolumn{5}{c|}{ Mean Level of Agreement } \\
\cline { 2 - 6 } & E1 & AM & E2 & A1 & A2 & E3 \\
\hline We have a low manufacturing cost strategy. & 3.00 & 5.00 & 4.00 & 4.50 & 4.00 & 2.50 \\
\hline $\begin{array}{l}\text { We make provision in our manufacturing strategy for } \\
\text { customers' demands (specifications). }\end{array}$ & 4.00 & 4.50 & 5.00 & 3.75 & 2.00 & 4.00 \\
\hline $\begin{array}{l}\text { We change our manufacturing strategy quickly according to } \\
\text { customer demands. }\end{array}$ & 4.00 & 3.00 & 4.00 & 2.25 & 2.00 & 3.00 \\
\hline $\begin{array}{l}\text { We customise some parts of our production process to meet } \\
\text { certain customers' orders. }\end{array}$ & 4.50 & 1.50 & 5.00 & 3.00 & 1.00 & 3.50 \\
\hline We keep minimum inventory in the production process. & 3.50 & 4.50 & 4.00 & 4.50 & 5.00 & 4.00 \\
\hline We manufacture on the basis of projected forecast. & 4.00 & 4.50 & 4.00 & 4.50 & 5.00 & 4.00 \\
\hline We have a pull system with specific customer orders. & 5.00 & 3.00 & 5.00 & 3.25 & 2.00 & 4.00 \\
\hline
\end{tabular}

As indicated in Table 6, the American manufacturer, European manufacturer 2, and Asian manufacturers 1 and 2 agreed that they employed a low manufacturing cost strategy (means of 4.00 to 5.00). Asian manufacturer 2 disagreed that it made provision in the manufacturing strategy for customers' demands (specifications) (mean of 2.00). The European manufacturers (1 and 2) were the only manufacturers that agreed that they changed their manufacturing strategy quickly according to customer demands (a mean of 4.00), while the Asian manufacturers disagreed that they implemented this practice (mean of 2.00 and 2.25). European manufacturers 1 and 2 agreed that they customised some parts of their production process to meet certain customers' orders (mean scores of 4.50 and 5.00 respectively), while the American manufacturer and Asian manufacturer 2 disagreed that they implemented the practice (means of 1.00 and 1.50 respectively). Asian manufacturer 2 recorded the highest mean value of 5.00 for keeping minimum inventory in the production process and also the highest mean value of 5.00 for manufacturing based on projected forecast. Only Asian manufacturer 2 did not agree that it had a pull system with specific customer orders (a mean of 2.00), indicating a lean supply chain strategy.

From the results, it is clear that all the manufacturers except European manufacturers 1 and 3 followed a low manufacturing cost strategy, indicating that both lean and agile supply chain strategies were used. All the manufacturers except Asian manufacturer 2 made provision for changes in their manufacturing. Also all the manufacturers except Asian manufacturers 1 and 2 actually changed their manufacturing strategy to meet customer demand. These changes indicate an agile supply chain strategy. Hence some used a MTS strategy, for example, low manufacturing cost and keeping minimum inventory, while others adopted an MTO strategy, such as changing manufacturing strategies according to customer demand. It is thus clear that both lean and agile supply chain strategies were evident in these locally manufactured models. A portfolio matrix was developed from the results in order to establish how the manufacturing strategies were aligned with supply chain strategies for each particular model (production line) (see Figure 3). The mean scores for two of the characteristics (low-cost manufacturing strategy and keeping inventory to a minimum in the production process) were matched against each other as shown in Table 7.

Table 7: Aligning Manufacturing Characteristics and Supply Chain Strategy

\begin{tabular}{|l|l|c|c|c|}
\hline \multirow{2}{*}{$\begin{array}{c}\text { Light } \\
\text { Vehicle }\end{array}$} & \multicolumn{1}{|c|}{ Manufacturing Characteristics } & Mean & $\begin{array}{c}\text { Strategy-Based } \\
\text { Manufacturing } \\
\text { Characteristics }\end{array}$ & $\begin{array}{c}\text { Supply Chain Strategy } \\
\text { Based on MTS and } \\
\text { MTO Strategy }\end{array}$ \\
\hline \multirow{2}{*}{ E1 } & Low-cost manufacturing strategy & 3.00 & MTS & Leagile \\
\cline { 2 - 5 } & Keep minimum inventory in production & 3.50 & MTS & Lean \\
\hline \multirow{2}{*}{ AM } & Low-cost manufacturing strategy & 5.00 & MTS & Lean \\
\cline { 2 - 5 } & Keep minimum inventory in production & 4.50 & MTS & Lean \\
\hline \multirow{2}{*}{ E2 } & Low-cost manufacturing strategy & 4.00 & MTS & Lean \\
\cline { 2 - 5 } & Keep minimum inventory in production & 4.00 & MTS & Lean \\
\hline \multirow{2}{*}{ A1 } & Low-cost manufacturing strategy & 4.50 & MTS & Lean \\
\cline { 2 - 5 } & Keep minimum inventory in production & 4.50 & MTS & Lean \\
\hline \multirow{2}{*}{ A2 } & Low-cost manufacturing strategy & 4.00 & MTS & Lean \\
\cline { 2 - 5 } & Keep minimum inventory in production & 5.00 & MTS & Agile \\
\cline { 2 - 5 } E3 & Low-cost manufacturing strategy & 2.50 & MTO & Lean \\
\cline { 2 - 5 }
\end{tabular}


Figure 3 provides a portfolio matrix for manufacturing characteristics.

\begin{tabular}{|l|c|c|}
\cline { 2 - 3 } $\begin{array}{l}\text { Minimum } \\
\text { inventory }\end{array}$ & $\begin{array}{c}\text { MATCH } \\
\text { (LEAN SUPPLY CHAIN) } \\
\text { European manufacturers 1 \& 2; } \\
\text { Asian manufacturers 1 \& 2; } \\
\text { American manufacturers }\end{array}$ & $\begin{array}{c}\text { MISMATCH } \\
\text { Hold } \\
\text { inventory }\end{array}$ \\
\cline { 2 - 3 } & MISMATCH \\
(AGILE SUPPLY CHAIN) & MATCH manufacturers 3 \\
\cline { 2 - 3 } & \multicolumn{2}{|c|}{ Low-cost strategy } \\
\hline
\end{tabular}

Figure 3: Portfolio Matrix for Manufacturing Characteristics

As indicated in Figure 3, based on the manufacturing characteristics, all the manufacturers were correctly positioned except for European manufacturer 3 which was wrongly positioned (mismatch). The manufacturer should not keep inventory to a minimum and at the same time engage in high-cost/differentiated supply chain, hence the mismatch in the alignment.

Research Question 3: What are the supply chain strategies of the different manufacturers based on the decision drivers of the supply chain?

The decision drivers of SCM were also analysed to understand how the different manufacturers used them. Mean level of agreement scores were used to present the results. Table 8 presents the responses of the different manufacturers on decision drivers of the supply chain.

Table 8: Responses Regarding Decision Drivers of the Supply Chain by Manufacturers

\begin{tabular}{|c|c|c|c|c|c|c|}
\hline \multirow{2}{*}{ Statements } & \multicolumn{6}{|c|}{ Mean Level of Agreement } \\
\hline & E1 & $\mathbf{A M}$ & E2 & A1 & A2 & $\mathbf{E 3}$ \\
\hline \multicolumn{7}{|l|}{ Production } \\
\hline We have excess capacity in our production process. & 3.00 & 4.50 & 2.00 & 3.00 & 1.00 & 2.50 \\
\hline We have flexible manufacturing processes. & 2.00 & 3.50 & 4.00 & 2.75 & 2.00 & 3.00 \\
\hline \multicolumn{7}{|l|}{ Inventory } \\
\hline $\begin{array}{l}\text { We work on a strict JIT system and therefore keep inventory holding in } \\
\text { the production process to a minimum. }\end{array}$ & 4.50 & 4.50 & 5.00 & 3.50 & 5.00 & 4.00 \\
\hline \multicolumn{7}{|l|}{ Location } \\
\hline We have decentralised distribution centres (stores) to serve our dealers. & 3.00 & 4.50 & 2.00 & 2.25 & 1.00 & 3.00 \\
\hline Our local strategic suppliers are located close to our production plant. & 5.00 & 2.50 & 5.00 & 3.00 & 3.00 & 4.50 \\
\hline \multicolumn{7}{|l|}{ Transportation } \\
\hline We make small and frequent shipments to our strategic customers. & 3.50 & 4.50 & 5.00 & 4.25 & 5.00 & 4.00 \\
\hline We receive small and frequent shipments from our strategic suppliers. & 4.00 & 4.00 & 4.00 & 3.50 & 5.00 & 4.00 \\
\hline $\begin{array}{l}\text { We make use of the lowest acceptable mode of transportation for parts } \\
\text { purchased from our strategic suppliers. }\end{array}$ & 4.50 & 4.50 & 3.00 & 3.75 & 3.00 & 3.50 \\
\hline $\begin{array}{l}\text { We make use of the lowest acceptable mode of transportation for vehicles } \\
\text { to our dealers. }\end{array}$ & 4.00 & 4.50 & 1.00 & 3.00 & 4.00 & 4.00 \\
\hline \multicolumn{7}{|l|}{ Information } \\
\hline $\begin{array}{l}\text { Information helps us to build master production schedules (forecasts) and } \\
\text { create delivery dates. }\end{array}$ & 5.00 & 4.50 & 5.00 & 4.25 & 5.00 & 4.50 \\
\hline $\begin{array}{l}\text { Information is used on actual demand to be transmitted quickly to reflect } \\
\text { real demand accurately. }\end{array}$ & 5.00 & 3.00 & 5.00 & 3.75 & 2.00 & 4.50 \\
\hline
\end{tabular}


Table 8 cont.

\begin{tabular}{|l|l|l|l|l|l|l|}
\hline Supplier Selection & 3.00 & 4.00 & 3.00 & 4.25 & 3.00 & 4.50 \\
\hline We select suppliers on the basis of low price/cost. & 5.00 & 4.00 & 5.00 & 3.00 & 5.00 & 4.50 \\
\hline We select suppliers on the basis of high-quality standards & 4.50 & 3.00 & 5.00 & 2.50 & 5.00 & 3.50 \\
\hline We select suppliers on the basis of dependability/sustainability. & 4.50 & 4.00 & 4.00 & 3.25 & 4.00 & 3.00 \\
\hline We select suppliers on the basis of flexibility. & 4.50 & 2.00 & 5.00 & 2.50 & 3.00 & 3.50 \\
\hline Pricing Strategy & 4.00 & 1.00 & 3.00 & 3.25 & 2.00 & 3.00 \\
\hline Our pricing strategy is determined by balancing supply and demand. & 3.50 & 1.00 & 4.00 & 4.00 & 1.00 & 4.00 \\
\hline $\begin{array}{l}\text { Our pricing strategy is based on low margins (low margins based on high } \\
\text { volume). }\end{array}$ & &
\end{tabular}

Table 8 reveals the following information:

- $\quad$ Production: The American manufacturer had excess capacity in its production process to a very great extent (a mean of 4.50), while Asian manufacturer 2 had no excess capacity (a mean of 1.00). Flexible manufacturing was practised to a great extent by European manufacturer 2 (a mean of 4.00) and by the American manufacturer (a mean of 3.9), while European manufacturer 1 and Asian manufacturer 2 implemented the practice only to a slight extent (a mean of 2.00). This means that the American manufacturer seemed to lean towards an agile supply chain strategy, while Asian manufacturer 2 was inclined towards a lean supply chain.

- Inventory: European manufacturer 2 and Asian manufacturer 2 worked on a strict JIT system to a great and very great extent (means of 4.00 to 5.00) and Asian manufacturer 1 tended to implement the practice to a great extent (a mean of 3.50). This result is in line with the previous findings, where all the respondents $(100 \%)$ indicated a lean supply chain strategy.

- Location: The American manufacturer used decentralised distribution centres (stores) to serve dealers to a very great extent (a mean of 4.50) and European manufacturers 1 and 3 to some extent (a mean of 3.00), while Asian manufacturer 1 used mainly centralised distribution systems (a mean of 1.00). European manufacturers 1,2, and 3 had local strategic suppliers located close to the production plant to a very great extent (means of 4.50 to 5.00). European manufacturers 1 and 2 had their strategic suppliers close to the manufacturing plant to a very great extent (a mean of 5.00). Decentralised distribution and close suppliers are indicative of an agile supply chain strategy.

- $\quad$ Transportation: All the manufacturers, on average, made small and frequent shipments to their strategic customers and suppliers to a great or very great extent (means of 3.5 to 5.00). The result also indicates that European manufacturer 1 and the American manufacturer made use of low-cost transportation modes for parts purchased from strategic suppliers to a very great extent (a mean of 4.50). European manufacturers 1 and 3, the American manufacturer, and Asian manufacturer 2 made use of the lowest acceptable mode of transportation for distributing vehicles to dealers, on average, to a great extent (means of 4.00 to 4.50 ), while European manufacturer 2 did not implement the practice at all (a mean of 1.00). This means that most of the manufacturers used low-cost and efficient means of transportation, which is a characteristic of a lean supply chain, while European manufacturer 2 used a flexible mode of transportation which is a characteristic of an agile supply chain.

- Information: All the manufacturers used forecasting information to build master production schedules and create delivery dates to a very great extent on average (a mean of 4.25 to 5.00). European manufacturers 1 , 2 , and 3 used information on actual demand that is transmitted quickly to accurately reflect real demand, on average, from a great extent to a very great extent (means of 4.00 to 5.00), while Asian manufacturer 2 implemented the practice to a slight extent (a mean of 2.00). Using forecasting information is indicative of a lean supply chain, while actual demand information indicates an agile supply chain. European manufacturers 1, 2, and 3 demonstrated both methods, which is indicative of a lean and agile (leagile) supply chain strategy.

- $\quad$ Supplier selection: The American manufacturer, Asian manufacturer 1, and European manufacturer 3 used low price as a criterion for selecting their suppliers to a great extent (means of 4.00 to 4.50), while European manufacturers 1 and 2 and Asian manufacturer 2 used this criterion to a moderate extent (a mean of 3.00). All the manufacturers, except Asian manufacturer 1, used high-quality standards to select 
suppliers, on average, from a great to very great extent (means of 4.00 to 5.00). European manufacturers 1 and 2 selected suppliers on the basis of dependability and sustainability to a very great extent (means of 4.50 to 5.00). Four of the manufacturers (European manufacturers 1 and 2, Asian manufacturer 2, and the American manufacturer) used flexibility as the criterion to a great extent in selecting their suppliers (means of 4.00 to 4.50 ). Low cost as a criterion indicates a lean supply chain, while flexibility indicates an agile supply chain strategy.

- $\quad$ Pricing strategy: European manufacturers 1 and 2 used a pricing strategy based on balancing supply and demand to a very great extent (mean values of 4.50 and 5.00 respectively). With regard to a pricing strategy based on low margins, European manufacturer 1 recorded the highest mean value of 4.00 (indicating a great extent), while the American manufacturer did not implement the strategy at all (a mean of 1.00). European manufacturers 1,2, and 3 and Asian manufacturer 1 used differentiation to a great extent (means of 3.50 to 4.00). The American manufacturer and Asian manufacturer 2 did not use differentiation as a pricing strategy (a mean of 1.00). Balancing supply and demand and a low margin are typical pricing strategies of a lean supply chain and this was used by European manufacturers 1,2, and 3. Differentiation is a typical pricing strategy for an agile supply chain and this was used by European manufacturers 1, 2, and 3 and Asian manufacturer 1.

The results reveal that both lean and agile supply chain practices are evident in the South African automotive industry. Table 9 represents an alignment of the decision drivers and supply chain strategies by the manufacturers.

Table 9: Aligning Decision Drivers to Supply Chain Strategies

\begin{tabular}{|l|l|l|}
\hline \multicolumn{1}{|c|}{ Drivers } & \multicolumn{1}{|c|}{ Lean Supply Chain } & \multicolumn{1}{c|}{ Agile Supply Chain } \\
\hline Production & Little excess capacity (E2 and E3; A2) & Excess capacity (E1; AM; and A1) \\
\hline Inventory & $\begin{array}{l}\text { Work on a strict JIT system (E1, E2, and E3, } \\
\text { AM, A1, and A2) }\end{array}$ & Decentralised distribution centres (E1 and E3; AM) \\
\hline Location & Centralised distribution centres (A1 and 2; E2) & Fast and flexible shipments to dealers (E2) \\
\hline Transportation & $\begin{array}{l}\text { Low-cost mode of transport to dealers (E1 and } \\
\text { E3; AM; A1, and A2) }\end{array}$ & $\begin{array}{l}\text { Transmits actual demand to reflect accurate demand } \\
\text { (E1, E2, and E3) }\end{array}$ \\
\hline $\begin{array}{l}\text { Source of } \\
\text { information } \\
\text { and A2) }\end{array}$ & $\begin{array}{l}\text { Based on quality \& cost (E1, E2, and E3; AM; } \\
\text { A1 and A2) }\end{array}$ & $\begin{array}{l}\text { Based on quality \& flexibility (E1, E2, and E3; AM; } \\
\text { A1 and A2) }\end{array}$ \\
\hline Supplier selection & Based on differentiation (AM and A2) \\
\hline Pricing & Based on low margins (E1, E2, and E3; A1) & \\
\hline
\end{tabular}

Therefore to some degree, there were mismatches between the drivers of supply chain and supply chain strategies among the supply chains.

\section{CONCLUSION}

Because of the complex nature and challenges of the South African automotive industry, there was a need to investigate the alignment between supply chain strategies and practices of local manufacturers of locally made light vehicles in South Africa. A theoretical background was provided and three research questions posed and answered. An exploratory and descriptive research methodology was employed and all light vehicle manufacturers that manufacture local models in South Africa were involved (total population) except for one. The respondents were selected by means of a purposive sampling technique based on in-depth interviews.

The paper revealed that all light vehicle manufacturers in South Africa employed a lean strategy for their inbound supply chain, and a number of the manufacturers had a lean supply chain strategy for their outbound supply chain. A number of the manufacturers also had an agile supply chain strategy in the outbound supply chain, which suggests a leagile supply chain strategy. It was also found that in some instances there was a mismatch between strategies and practices in the areas of product characteristics, manufacturing characteristics, and the decision drivers of the supply chain. Mismatches are the root cause of the problems plaguing many supply chains, and therefore supply chain strategies that are based on a one-size-fits-all strategy will fail. An effective supply chain strategy must 
be aligned with a company's business strategy, since a mismatch generally leads to significant problems in business operations. It is therefore imperative for South African supply chain managers to understand their customers' needs and to choose and implement the right strategy for the supply chain to satisfy customer demands. By implementing the optimal supply chain strategy, the South African automotive industry would improve its competitive position. In conclusion, optimal supply chain strategies are implemented by the light vehicle manufacturers; however, there is a mismatch between practices and strategies to some extent.

Furthermore, the paper study established that the product characteristics, manufacturing characteristics, and decision drivers of SCM are crucial when choosing an optimal supply chain strategy. An organisation can employ a lean (efficient), an agile (responsive), or a combination of lean and agile (leagile) supply chain strategy, which must be aligned to the business strategy. An important aspect that this study revealed is that a lean supply chain is still a dominant strategy in many companies. A limitation of the study is that one of the light vehicle manufacturers of local models was unwilling to participate in the study. It is not known if the findings would have been different with the involvement of that company. For further research, it is recommended that the study be carried out for light vehicle manufacturers in other countries.

\section{AUTHOR INFORMATION}

Intaher Marcus Ambe, University of South Africa (UNISA), Department of Business Management, South Africa. E-mail: ambeim@unisa.ac.za

\section{REFERENCES}

1. $\quad$ AIEC. (2012), Automotive export manual. Arcadia, Pretoria, South Africa.

2. Agarwal, A., Shankar, R., \& Tiwari, M. K. (2007). Modeling agility of supply chains. Industrial Marketing Management, 36, 443-57.

3. Alfaro, A. L., Bizuneh, G., Moore, R., Ueno, S., \& Wang, R. (2012). South Africa: Automotive cluster, microeconomics of competitiveness. Harvard Business School: 1260, Kennedy School of Government: PED-329.

4. Babbie, E., \& Mouton, J. (2007). The practice of social research (South African edition). Cape Town: Oxford University Press.

5. Bowersox, D. J., Closs, D. J., \& Cooper, M. B. (2010). Supply chain logistics management (3 ${ }^{\text {rd }}$ ed.). Singapore: McGraw-Hill.

6. Chopra, S., \& Meindl, P. (2010). Supply chain management: Strategy, planning and operation. Upper Saddle River, NJ: Pearson.

7. Christopher, M., \& Towill, D. R. (2000). Supply chain migration from lean and functional to agile and customised. Supply Chain Management: An International Journal, 5(4), 206-213.

8. Christopher, M., \& Towill, D. R. (2002). Developing market-specific supply chain strategies. International Journal of Logistics Management, 13(1), 1-14.

9. Cohen, S., \& Rousell, J. (2005). Strategic supply chain management: the five disciplines for top performance. New York: McGraw-Hill.

10. Duarte, S., \& Machado, V. C. (2011). Manufacturing paradigms in supply chain management. International Journal of Management Science and Engineering Management, 6(5), 328-42.

11. El-Tawy, N., \& Gallear, D. (2011). Leanness and agility as means for improving supply chains: A case study on Egypt. European, Mediterranean and Middle East Conference proceedings on Information Systems, Athens, Greece, pp. 809-41.

12. Fisher, M. L. (1997). What is the right supply chain for your product? Harvard Business Review, March/April, 105-116.

13. Gray, P. S., Williamson, J. B., Karp, D. A., \& Dalphin, J. R. (2007). The research imagination: An introduction to qualitative and quantitative methods. New York: Cambridge.

14. Hines, T. (2006). Supply chain strategies: Customer-driven and customer focused. Boston: Elsevier.

15. Ismail, H. S., \& Sharifi, H. (2006). A balanced approach to building agile supply chains. International Journal of Physical Distribution and Logistics Management, 26(6), 431-444. 
16. Iskanius, P. (2006). An agile supply chain for a project-oriented steel product network. Retrieved 1 July 2008 from http:www.herkules.oulu.fi/isbn9574281489

17. Jonsson, P. (2008). Logistics and supply chain management. UK: McGraw-Hill.

18. Kehbila, A. G., Ertel, J., \& Brent, A. C. (2009). Strategic corporate environmental management within the South African automotive industry: motivations, benefits, hurdles. Corporate Social Responsibility and Environmental Management, 2009.

19. Krishnamurthy, R., \& Yauch, C.A. (2007). Leagile manufacturing: a proposed corporate infrastructure. International Journal of Operations and Production Management, 27(6), 588-604.

20. Lee, H. L. (2002). Aligning supply chain strategies with product uncertainties. California Management Review, 44, 105-119.

21. Li, X., Chung, C., Goldsby, T. J., \& Holsapple, C. W. (2008). A unified model of supply chain agility: The work-design perspective. The International Journal of Logistics Management, 19(3), 408-435.

22. Lo, S., \& Power, D. (2010). An empirical investigation of the relationship between product nature and supply chain strategy. Supply Chain Management, 15(2), 139-153.

23. Mason-Jones, R., Naylor, B., \& Towill, D. R. (2000). Engineering the leagile supply chain. International Journal of Agile Management Systems, 1, 54-61.

24. McGivern, Y. (2006). The practice of market and social research: An Introduction ( $2^{\text {nd }}$ ed.). England, Prentice Hall.

25. Nel, J. D., \& Badenhorst-Weiss, J. A. (2010). Supply chain design: some critical questions. Journal of Transport and Supply Chain Management, 4(1), 198-223.

26. Qi, Y., Boyer, K. K., \& Zhao, X. (2009). Supply chain strategy, product characteristics, and performance impact: Evidence from Chinese manufacturers. Decision Sciences, 40(4), 667-696.

27. Qrunfleh, S., \& Tarafdar, M. (2013). Lean and agile supply chain strategies and supply chain responsiveness: The role of strategic supplier partnership and postponement. Supply Chain Management: An International Journal, 18(6), 571-582.

28. Rahimnia, F., Moghadasian, M., \& Castka, P. (2009). Benchmarking leagility in services. The case of fast food restaurant chains in Iran. Benchmarking: An International Journal, 16(6), 799-816.

29. South Africa.info. (2008). South Africa's automotive industry. Retrieved January 2010 from http://www.southafrica.info/business/economy/sectors/automotive-overview.htm

30. Sanchez, A. M., \& Perez, M. P. (2005). Supply chain flexibility and firm performance: A conceptual model and empirical study in the automotive industry. International Journal of Operations and Production Management, 25(7), 681-700.

31. Sayuti, N. M. (2011). Critical determinants of agile supply chain in buyer and supplier relationships: A literature review and future direction. International Journal of Business and Management Studies, 3(1), 287-98.

32. Sebastiao, H. J., \& Golicic, S. L. (2008). Supply chain strategy for nascent firms in emerging technology markets. Journal of Business Logistics, 21(1), 75-91.

33. Stavrulaki, E., \& Davis, M. (2010). Aligning products with supply chain processes and strategy. The International Journal of Logistics Management, 21(1), 127-51.

34. Shukla, K. R., Garg, D., \& Agarwal, A. (2011). Understanding of supply chain: A literature review. International Journal of Engineering Science and Technology (IJEST), 3(3), 2059-72.

35. Taylor, D. A. (2004). Supply chains. A manager's guide. US: Pearson Education.

36. Vinodh, S, Sundararaj, G., \& Devadasan, S. R. (2009). Total agile design system model via literature exploration. Industrial Management and Data System, 109(4), 570-588.

37. Womack, J. P., \& Jones, D. T. (2003). Lean thinking, banish waste and create wealth in your corporation. New York: Simon \& Schuster. 
NOTES 